Publisher: Research Council of Science and Technology, Biratnagar, Nepal p. 1

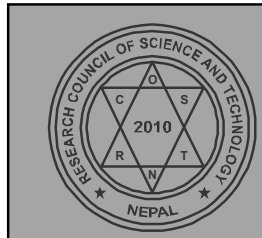

\title{
BIBECHANA
}

A Multidisciplinary Journal of Science, Technology and Mathematics

ISSN 2091-0762 (print), 2382-5340 (online)

Journal homepage: http://nepjol.info/index.php/BIBECHANA

\section{Study the effect of sodium nitrite as a green corrosion inhibitor for the sputter-deposited tungsten-based ternary alloys in $0.5 \mathrm{M}$ NaCl solution}

\author{
Durga Bhakta Pokharel ${ }^{1}$, Dhruba Babu Subedi ${ }^{1}$, Jagadeesh Bhattarai ${ }^{2, *}$ \\ ${ }^{1}$ Department of Chemistry, Tri-Chandra M. Campus, Tribhuvan University, Kathmandu \\ ${ }^{2}$ Central Department of Chemistry, Tribhuvan University, Kirtipur, Kathmandu, Nepal \\ *E-mail:bhattarai_05@yahoo.com \\ Accepted for publication: December 4, 2014
}

\begin{abstract}
Effects of sodium nitrite on the corrosion resistance and mechanism of the sputter-deposited W-80Cr$10 \mathrm{Zr}$ and $\mathrm{W}-42 \mathrm{Cr}-5 \mathrm{Ni}$ alloys were studied using corrosion tests and open circuit potential (OCP) measurements in $0.5 \mathrm{M} \mathrm{NaCl}$ solution, open to air at $25^{\circ} \mathrm{C}$. The corrosion resistance property of the $\mathrm{W}-80 \mathrm{Cr}-10 \mathrm{Zr}$ and $\mathrm{W}-42 \mathrm{Cr}-5 \mathrm{Ni}$ alloys was enhanced by the use of environmental friendly corrosion inhibitor of sodium nitrite. Higher corrosion resistance property and passivation behavior was observed for the $\mathrm{W}-42 \mathrm{Cr}-5 \mathrm{Ni}$ alloy than that for the $\mathrm{W}-80 \mathrm{Cr}-10 \mathrm{Zr}$ alloy based on the corrosion rate and OCP measurements. Adsorption process obeyed Langmuir adsorption isotherm to explain the corrosion inhibition mechanism of the alloys by sodium nitrite solution. The standard free energy change of adsorption of sodium nitrite on the $\mathrm{W}-80 \mathrm{Cr}-10 \mathrm{Zr}$ and $\mathrm{W}-42 \mathrm{Cr}-5 \mathrm{Ni}$ alloys was found to be $23.70 \mathrm{KJ} / \mathrm{mole}$ and $-23.38 \mathrm{KJ} / \mathrm{mole}$, respectively which suggested that sodium nitrite is strongly adsorbed on the surfaces of the alloy surfaces by physical adsorption, not by the chemisorption. As a result the corrosion resistance property of the alloys was significantly increased with increasing the sodium nitrite concentration. From the OCP measurement, it is concluded that sodium nitrite acts as an anodic corrosion inhibitor, because the OCPs of the alloys in presences of the corrosion inhibitors were shifted to more positive direction with increasing the concentration of sodium nitrite in $0.5 \mathrm{M}$ $\mathrm{NaCl}$ solution open to air at $25^{\circ} \mathrm{C}$.
\end{abstract}

DOI: http://dx.doi.org/10.3126/bibechana.v12i0.11670

(C) 2014 RCOST: All rights reserved.

Keywords: Green inhibitor; Corrosion; Tungsten-based alloys; $0.5 \mathrm{M}$ NaCl solution; Inhibition mechanism.

\section{Introduction}

Corrosion is an undesirable phenomenon which destroys the properties of metallic materials and shortens life of the materials $[1,2]$. It is mainly due to the spontaneous instability of the metallic substances that results from the charge-transfer reactions at interfaces between the metallic materials and their environments [3]. The corrosion is one of the major industrial, scientific and technological 
problems. A small careless regarding to the corrosion at the beginning of implementation of any system plants and processes can cause major economic loss during their operation.

Corrosion science and engineering is interrelated each other which is a multidisciplinary subject, probably unique in crossing the borders of almost all branches of science and technology. Engineering materials are generally developed based on their corrosion resistance properties. The lack of information about the corrosion resistance properties of the engineering materials may be one of the causes of wastages of much money, labor as well as destroy the quality of the materials in a short time. Hence, the works of engineers and technologists become unreliable without testimony of corrosion properties of the engineering materials. Early in the past, engineers and technologists did not take into consideration the importance of the corrosion study during the initial stage of the designing of materials with the thought that the corrosion problems could be avoided later by additional surface treatments at the time of problems (corrosion) observe [1]. In general, two things should be significantly taken into mind of engineers and technologists before the engineering materials are subjected for applications in any fields. Firstly, under what conditions it is used and secondly, how it is processed. Nowadays, the engineers as well as the technologists have realized that corrosion behavior of the materials used in the system plants and processes should be solved at early stage of installations.

The control of such unwanted corrosion phenomena is a subject of tremendous technological and industrial significances. The corrosion can be controlled using different techniques. Nowadays, the corrosion control method of metallic materials using various types of eco-friendly green corrosion inhibitors is becoming a fundamental academic and research concerns of corrosion scientists, engineers and technologists [1,2]. The corrosion inhibitor is a chemical substance that when added in small amounts to a corrosive environment, effectively decreases the corrosion rate of the metallic materials exposed to that environment [1]. Very low concentrations of chemical species with special characteristics, that can intervene the corrosion kinetics and thereby control the corrosion is generally term as corrosion inhibitor. There are several types of such inhibitors designated are inorganic, organic, vapor-phase inhibitors and so on. The use of such inhibitor to retard the corrosion rate of the materials is becoming one of the widely used corrosion control methods.

Practical criteria for the selection of corrosion inhibitors from the variety of inorganic and organic compounds with inhibiting properties are not only their inhibition efficiency but also safety of use, economic constraints and compatibility with other chemicals in the system as well as the environmental concerns. In recent years, many alternative eco-friendly green inorganic [4-7] and organic [7-12] corrosion inhibitors are developed. In the past, a lot of chemical compounds were used as the corrosion inhibitors to control the corrosion kinetics of different metals and alloys in aggressive environments [8-17]. However, all of these corrosion inhibitors were not eco-friendly green inhibitors. For example, chromate (VI) is reported as one of the most effective inhibitors, but it is toxic to human beings $[18,19]$. Therefore, nowadays $\mathrm{Cr}(\mathrm{VI})$ is not generally practiced as a corrosion inhibitor. There is great interest in replacing chromates with effective and non-hazardous alternatives eco-friendly green corrosion inhibitors. Nitrites, molybdate, tungstate are now being increasingly used as eco-friendly green inorganic corrosion inhibitors due to their low order of toxicity [20-30].

It was reported that the sputter-deposited amorphous/nanocrystalline $\mathrm{W}-\mathrm{xZr}-\mathrm{yCr}$ [31-37] and $\mathrm{W}$-xCryNi [31, 38-41] alloys were spontaneously passivated showing higher corrosion resistance properties than those of their alloy-constituting elements in different aggressive acidic to alkaline solutions. In 
this context, the present work is focused to study the effects of the eco-friendly green corrosion inhibitor of sodium nitrite on the corrosion behavior and inhibition mechanism of two sputterdeposited $\mathrm{W}-80 \mathrm{Cr}-10 \mathrm{Zr}$ and $\mathrm{W}-42 \mathrm{Cr}-5 \mathrm{Ni}$ alloys in $0.5 \mathrm{M} \mathrm{NaCl}$ solution, open to air at $25^{\circ} \mathrm{C}$ using corrosion tests and open circuit potential measurement.

\section{Materials and Experimental Methods}

\subsection{Ternary $\mathrm{W}-80 \mathrm{Cr}-10 \mathrm{Zr}$ and $\mathrm{W}-42 \mathrm{Cr}-5 \mathrm{Ni}$ alloys}

The instrument used and conditions subjected for sputter deposition of these two sputter-deposited ternary alloys were same as those described elsewhere [32, 33, 38, 41]. X-ray diffractometer with $\mathrm{CuK}_{\alpha}$ radiation at $\theta-2 \theta$ mode and electron probe microanalysis were used to determine the composition and structure of the sputter-deposited W-80Cr-10Zr [32, 33] and W-42Cr-5Ni [38, 41] alloys, respectively. Apparent grain size of the alloys was estimated using Scherrer's formula from the most intense XRD peak [42].

\subsection{Corrosion rate measurement}

The corrosion test of the $\mathrm{W}-80 \mathrm{Cr}-10 \mathrm{Zr}$ and $\mathrm{W}-42 \mathrm{Cr}-5 \mathrm{Ni}$ alloys was carried out in $0.5 \mathrm{M} \mathrm{NaCl}$ solution with different concentrations (i.e. 200, 400, 800, 1200, 1600 and 2400 ppm) of sodium nitrite. Before each corrosion test, the alloy specimens were polished mechanically using silicon carbide paper having grit number 1500 in cyclohexane. The polished alloy specimens were rinsed with acetone and dried in air to obtain reproducible result. The weight loss method was used to estimate the average corrosion rate of the alloys using the equation 1 [2]. The estimation of the average corrosion rate was carried out two times or more so as to obtained delimited results.

$$
\text { Corrosion Rate }(\mathrm{mm} / \mathrm{y})=\frac{\Delta \mathrm{w} \times 8760 \times 10}{\mathrm{~d} \times \mathrm{A} \times \mathrm{t}}
$$

where, $\Delta \mathrm{w}$ is the weight loss of the alloy specimen in gram $(\mathrm{g}), \mathrm{d}$ is the density of the alloy specimen in $\mathrm{g} / \mathrm{cm}^{3}, \mathrm{~A}$ is area of the alloy specimen in $\mathrm{cm}^{2}$ and $\mathrm{t}$ is the time of immersion in hour.

\subsection{Corrosion inhibition efficiency and mechanism studies}

In order to explain the corrosion inhibition mechanism based on the corrosion rate for the corrosion control of the sputter-deposited $\mathrm{W}-80 \mathrm{Cr}-10 \mathrm{Zr}$ and $\mathrm{W}-42 \mathrm{Cr}-5 \mathrm{Ni}$ alloys in $0.5 \mathrm{M} \mathrm{NaCl}$ and $1 \mathrm{M} \mathrm{NaOH}$ solutions open to air at $25^{\circ} \mathrm{C}$ in presence of sodium nitrite concentrations, the inhibition efficiency $\left(\mathrm{IE}_{\mathrm{CR}}\right)$ and the degree of surface coverage $(\theta)$ of the inhibitor molecule adsorbed on the alloy surface $[43,44]$ were estimated using equations (2) and (3), respectively, where, $\mathrm{CR}_{\text {(unhib.) }}$ and $\mathrm{CR}_{\text {(inhib.) }}$ are the corrosion rates of the alloys in absence and presence of the corrosion inhibitor of sodium nitrite, respectively. The Langmuir adsorption isothermal equation (4) was used to study the corrosion inhibition mechanism. The adsorptive equilibrium constant $\left(\mathrm{K}_{\mathrm{ads}}\right)$ value was estimated from the intercept of a straight line obtained by plotting $\mathrm{C}_{\text {inhib. }} / \theta$ vs $\mathrm{C}_{\text {inhib. }}$. Furthermore, the $\mathrm{K}_{\text {ads }}$ value was used to estimate the standard free energy change of adsorption $\left(\Delta \mathrm{G}_{\mathrm{ads}}^{\mathrm{o}}\right)$ using equations (5) and (6) [43, 44]. 


$$
\begin{aligned}
& \mathrm{IE}_{\mathrm{CR}}(\%)=\frac{\mathrm{CR}_{\text {(unhib.) }}-\mathrm{CR}_{\text {(inhib .) }}}{\mathrm{CR}_{\text {(unhibit .) }}} \times 100 \\
& \theta=\frac{\mathrm{CR}_{\text {(unhib .) }}-\mathrm{CR}_{\text {(inhib .) }}}{\mathrm{CR}_{\text {(unhib .) }}} \\
& \frac{\mathrm{C}_{\text {inhib. }}}{\theta}=\left(\frac{1}{\mathrm{~K}_{\text {ads }}}\right)+\mathrm{C}_{\text {inhib. }} \\
& \mathrm{K}_{\text {ads }}=\frac{1}{55.5} \exp \left(-\frac{\Delta \mathrm{G}_{\text {ads }}^{o}}{\mathrm{RT}}\right) \\
& \Delta \mathrm{G}_{\text {ads }}^{\mathrm{o}}=-\mathrm{RT} \ln \left(55.5 \times \mathrm{K}_{\text {ads }}\right)
\end{aligned}
$$

where, $\mathrm{C}_{\text {inhib. }}$ is the inhibitor concentration, $\mathrm{R}$ is gas constant, $\mathrm{T}$ is absolute temperature and the value of 55.5 is the molar concentration of water in solution.

\subsection{Open circuit potential measurement}

The open circuit potential (OCP) of the sputtered $\mathrm{W}-80 \mathrm{Cr}-10 \mathrm{Zr}$ and $\mathrm{W}-42 \mathrm{Cr}-5 \mathrm{Ni}$ alloys was measured in $0.5 \mathrm{M} \mathrm{NaCl}$ solution open to air at $25^{\circ} \mathrm{C}$ containing different concentrations (i.e. 200, 400, 800, 1200,1600 and $2400 \mathrm{ppm}$ ) of sodium nitrite as a green corrosion inhibitor. The test specimens of the alloys were first mechanically polished by silicon carbide paper (grit number 1500) in cyclohexane, rinsed with acetone and dried in air to obtain reproducible results. Then, the test specimens of the alloys were clipped by a sample holder that was made by welding the crocodile pin with a titanium rod. The readings were taken immediately after immersion of the alloy specimen in the electrolytic solution until 72 hours at different time intervals. The OCP measurement was repeated two times or more. All the electrolytic solutions used in the present work were prepared using AR grade chemicals in distilled water. A saturated calomel electrode (SCE) and the sputter-deposited alloy specimens were used as reference and working electrodes, respectively.

\section{Results and Discussion}

\subsection{Effects of sodium nitrite inhibitor in the corrosion rate of alloys}

The effect of different concentrations (i.e., 200, 400, 800, 1200, 1600 and $2400 \mathrm{ppm}$ ) of sodium nitrite in the corrosion rate of the sputter-deposited $\mathrm{W}-80 \mathrm{Cr}-10 \mathrm{Zr}$ and $\mathrm{W}-42 \mathrm{Cr}-5 \mathrm{Ni}$ alloys was estimated after immersion for $240 \mathrm{~h}$ in $0.5 \mathrm{M} \mathrm{NaCl}$ solution open to air at $25^{\circ} \mathrm{C}$. The corrosion rate of both the alloys was decreased with increasing the concentrations of sodium nitrite between 200 to $2400 \mathrm{ppm}$ in $0.5 \mathrm{M} \mathrm{NaCl}$ solution as depicted in Fig. 1. The corrosion rate of both alloys was found to be lowest in $2400 \mathrm{ppm}$ of sodium nitrite in $0.5 \mathrm{M} \mathrm{NaCl}$ solution and it is about one order of magnitude lower than in $0.5 \mathrm{M} \mathrm{NaCl}$ solution in addition of $2400 \mathrm{ppm}$ sodium nitrite concentration. These results revealed that the use of sodium nitrite as an eco-friendly green corrosion inhibitor enhanced to increase the corrosion resistance properties of the sputter-deposited ternary $\mathrm{W}-80 \mathrm{Cr}-10 \mathrm{Zr}$ and $\mathrm{W}-42 \mathrm{Cr}-5 \mathrm{Ni}$ alloys in near neutral $0.5 \mathrm{M} \mathrm{NaCl}$ solution at $25^{\circ} \mathrm{C}$. It is meaningful for mentioning here that the corrosion rate of the $\mathrm{W}-42 \mathrm{Cr}-5 \mathrm{Ni}$ alloy in absence and presence of sodium nitrite is lower than that for $\mathrm{W}-80 \mathrm{Cr}$ $10 \mathrm{Zr}$ alloy as shown Fig. 1. 


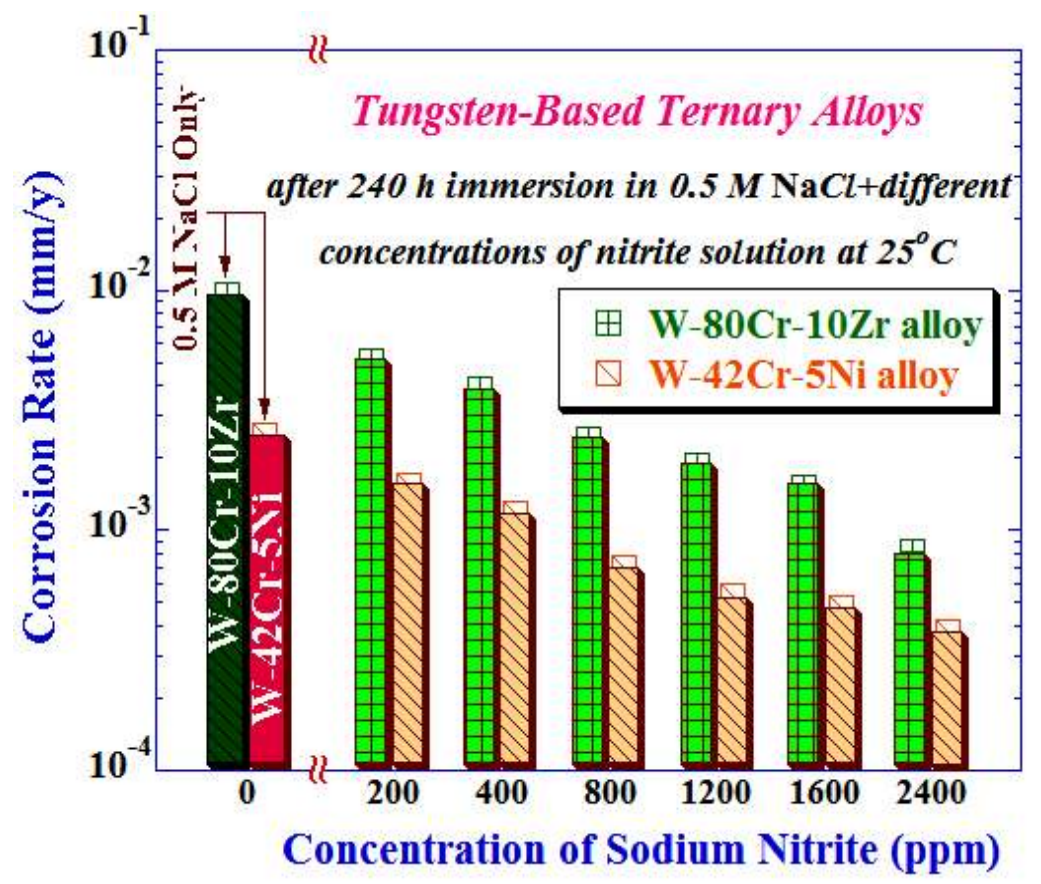

Fig. 1: Changes in the corrosion rates of the sputter-deposited $\mathrm{W}-80 \mathrm{Cr}-10 \mathrm{Zr}$ and $\mathrm{W}-42 \mathrm{Cr}-5 \mathrm{Ni}$ alloys after immersion for 240 hours in $0.5 \mathrm{M} \mathrm{NaCl}$ solution, open to air at $25^{\circ} \mathrm{C}$, as a function of the concentration of sodium nitrite.

\subsection{Efficiency and mechanism of corrosion inhibition on alloys by sodium nitrite}

The inhibition efficiency of sodium nitrite in $0.5 \mathrm{M} \mathrm{NaCl}$ solution for the $\mathrm{W}-80 \mathrm{Cr}-10 \mathrm{Zr}$ and $\mathrm{W}-42 \mathrm{Cr}$ $5 \mathrm{Ni}$ alloys is increased with increasing sodium nitrite concentrations as shown in Fig 2. The maximum inhibition efficiency of about $81-92 \%$ was obtained between 1200 to $2400 \mathrm{ppm}$ of sodium nitrite in $0.5 \mathrm{M} \mathrm{NaCl}$ solution for the W-80Cr-10Zr alloy whereas it was found to be between 80 to 85 $\%$ for the W-42Cr-5Ni alloy as shown in Fig. 2 (a). It is found that the most efficient corrosion inhibitor concentration of sodium nitrite is found to be at $2400 \mathrm{ppm}$ for both the alloys in $0.5 \mathrm{M} \mathrm{NaCl}$ solution, open to air at $25^{\circ} \mathrm{C}$. The inhibition action of the corrosion inhibitor of sodium nitrite was found to obey the Langmuir isotherm model of adsorption. Consequently, the increase in the percentage corrosion inhibition efficiency with increasing inhibitor concentrations indicated that the sodium nitrite acting as adsorption inhibitor to decrease the corrosion rate of the sputter-deposited W$80 \mathrm{Cr}-10 \mathrm{Zr}$ and $\mathrm{W}-42 \mathrm{Cr}-5 \mathrm{Ni}$ alloys in $0.5 \mathrm{M} \mathrm{NaCl}$ solution at $25^{\circ} \mathrm{C}$.

The Langmuir adsorption isotherm model was performed to have more insights into the mechanism of corrosion inhibition of sodium nitrite on the sputter-deposited $\mathrm{W}-80 \mathrm{Cr}-10 \mathrm{Zr}$ and $\mathrm{W}-42 \mathrm{Cr}-5 \mathrm{Ni}$ alloys in $0.5 \mathrm{M} \mathrm{NaCl}$ solution at $25^{\circ} \mathrm{C}$. In order to obtain adsorption isotherm to explain the corrosion inhibition mechanism of sodium nitrite for the $\mathrm{W}-80 \mathrm{Cr}-10 \mathrm{Zr}$ and $\mathrm{W}-42 \mathrm{Cr}-5 \mathrm{Ni}$ alloys, the $\theta$ value was estimated from the weight loss measurement at different concentrations of sodium nitrite. The process of inhibitor adsorption on the surface of the alloys can be described by different isotherms, from which Langmuir model is simplest and based on the assumption that all adsorption sites are equivalent 
and the particle binding occurs independently from nearby sites being occupied or not as expressed in equation (4).

Figure 2 (b) show the relationship between $\mathrm{C}_{\text {inhib }} / \theta$ and concentration of sodium nitrite $\left(\mathrm{C}_{\text {inhib.) }}\right.$ for the $\mathrm{W}-80 \mathrm{Cr}-10 \mathrm{Zr}$ and $\mathrm{W}-42 \mathrm{Cr}-5 \mathrm{Ni}$ alloys in $0.5 \mathrm{M} \mathrm{NaCl}$ solution. The linear correlation coefficient $\left(\mathrm{R}^{2}\right)$ and the slope of the straight line for both the alloys were found to almost unity. These results indicated that the adsorption process obeyed Langmuir adsorption isotherm to explain the corrosion inhibition mechanism on the surface of the alloys by sodium nitrite in $0.5 \mathrm{M} \mathrm{NaCl}$ solution.

It is meaningful for mentioning here that there is no interaction between the adsorbed corrosion inhibitor molecules, the energy of adsorption is independent with $\theta$, the alloy surfaces contain a fixed number of adsorption sites and each site holds one adsorbed species according to the Langmuir isotherm model [23]. In literature, it was reported that the high $K_{\text {ads }}$ value (greater than $100 \mathrm{~mol} / \mathrm{g}$ ) attributes to stronger and more stable adsorbed layer formation on the metals or/and alloys surfaces $[45,46]$. It was reported that the $\Delta \mathrm{G}_{\text {ads }}^{\mathrm{o}}$ values of metals or alloys around $-20 \mathrm{KJ} / \mathrm{mole}$ or lower indicate adsorption of inhibitors onto material surface with electrostatic interaction is due to physical adsorption, while those around or higher (more negative) than $-40 \mathrm{KJ} /$ mole involve charge sharing between inhibitor molecules and material surfaces is of chemisorption [47]. Negative values of $\Delta \mathrm{G}_{\text {ads }}^{\circ}$ ensure the spontaneity of the adsorption process and stability of the adsorbed layer of the corrosion inhibitors on the materials surfaces. In the present study, the $\Delta \mathrm{G}_{\text {ads }}^{0}$ values for sodium nitrite as corrosion inhibitor in $0.5 \mathrm{M} \mathrm{NaCl}$ solution at $25^{\circ} \mathrm{C}$ for the sputter-deposited $\mathrm{W}-80 \mathrm{Cr}-10 \mathrm{Zr}$ and $\mathrm{W}$ $42 \mathrm{Cr}-5 \mathrm{Ni}$ alloys were found to be -23.70 and $-23.38 \mathrm{KJ} / \mathrm{mole}$, respectively, that are consistent with literatures for physical type of adsorption. Hence authenticates physical adsorption of the inhibitors on the surface of $\mathrm{W}-80 \mathrm{Cr}-10 \mathrm{Zr}$ and $\mathrm{W}-42 \mathrm{Cr}-5 \mathrm{Ni}$ alloys. This implies that the corrosion inhibitor of sodium nitrite adhere on the surfaces of the sputter-deposited alloys and so give more efficient inhibition effects to decrease the corrosion rate of the alloys in $0.5 \mathrm{M} \mathrm{NaCl}$ solution, open to air at $25^{\circ} \mathrm{C}$.

\subsection{Open circuit potential}

The open circuit potential (OCP) or corrosion potential $\left(\phi_{\text {corr. }}\right)$ measurement was carried out for a better understanding of the corrosion behavior of the W-80Cr- $10 \mathrm{Zr}$ and $\mathrm{W}-42 \mathrm{Cr}-5 \mathrm{Ni}$ alloys in $0.5 \mathrm{M}$ $\mathrm{NaCl}$ solution open to air at $25^{\circ} \mathrm{C}$ in absence and presence of sodium nitrite as the corrosion inhibitor. Figure 3 shows the changes in the open circuit potential for the alloy specimens after immersion for 72 hours in $0.5 \mathrm{M} \mathrm{NaCl}$ solution at $25^{\circ} \mathrm{C}$ in absence and presence of different concentrations of sodium nitrite. It is clearly showed that $\mathrm{OCP}$ of the alloys in $0.5 \mathrm{M} \mathrm{NaCl}$ solution with different concentrations of sodium nitrite is shifted to more positive or noble direction with increasing the concentrations of sodium nitrite after immersion for 72 hours as shown in Fig. 3. These results revealed that the eco-friendly green corrosion inhibitor of sodium nitrite used in the present study acts as the anodic inhibitor for the sputter-deposited ternary W-80Cr-10Zr and W-42Cr-5Ni alloys in near neutral $0.5 \mathrm{M} \mathrm{NaCl}$ solution, because the OCP of the alloy is shifted to more positive direction in all concentrations in both the alloys. In particular, the shifting of the OCP towards the more positive direction with increasing the concentration of the sodium nitrite is more clearly observed for the $\mathrm{W}$ $42 \mathrm{Cr}-5 \mathrm{Ni}$ alloy than for the $\mathrm{W}-80 \mathrm{Cr}-10 \mathrm{Zr}$ alloy which is consistent with the corrosion rate result as shown above in Fig. 1. 

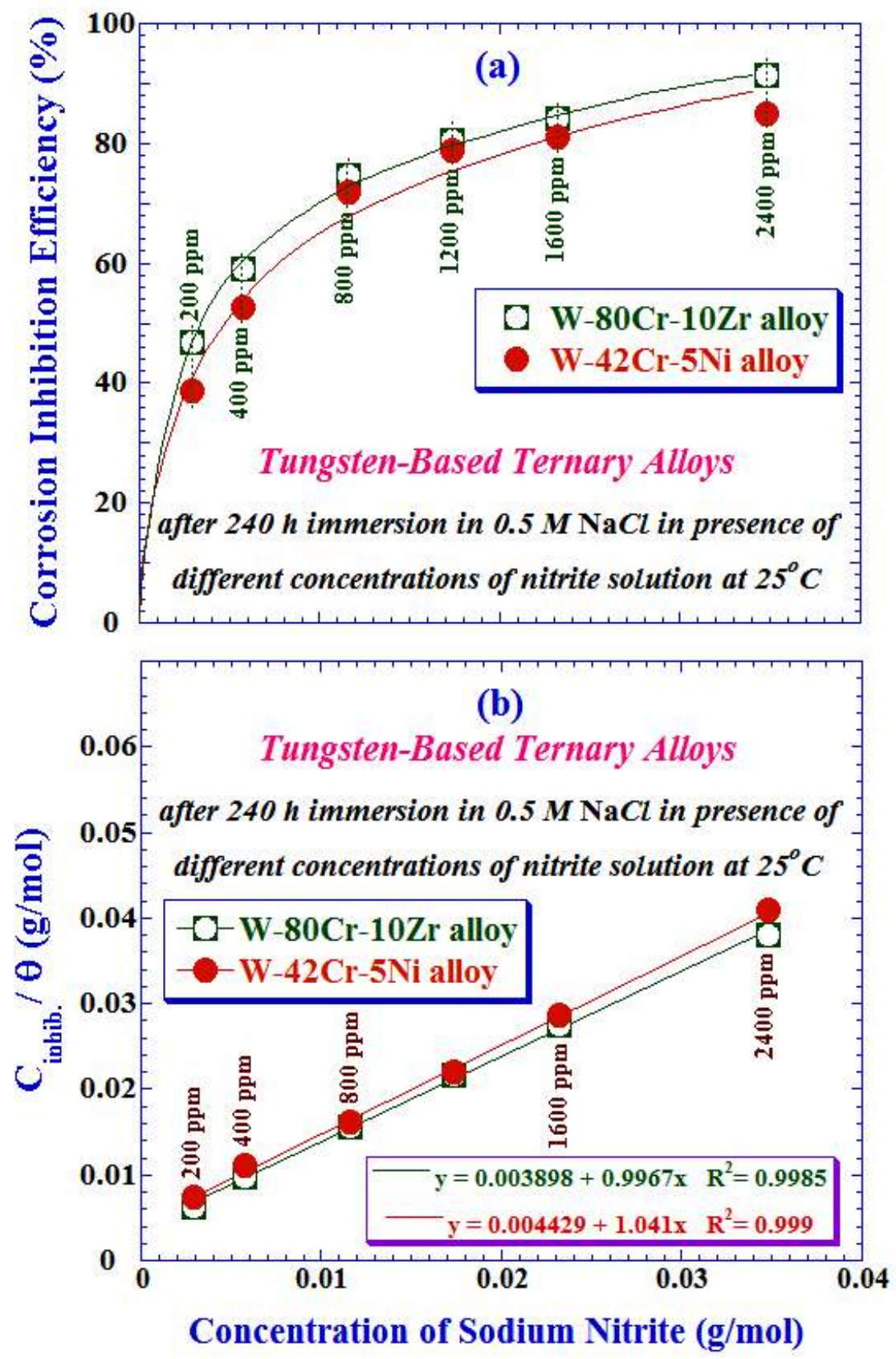

Fig. 2: (a) Changes in corrosion inhibition efficiency and (b) Langmuir plot for the sputterdeposited ternary (a) $\mathrm{W}-42 \mathrm{Cr}-5 \mathrm{Ni}$ and (b) $\mathrm{W}-80 \mathrm{Cr}-10 \mathrm{Zr}$ alloys after immersion for 240 hours in $0.5 \mathrm{M} \mathrm{NaCl}$ solution open to air at $25^{\circ} \mathrm{C}$. 
Pokharel et al. / BIBECHANA 12 (2015) 1-12: p. 8
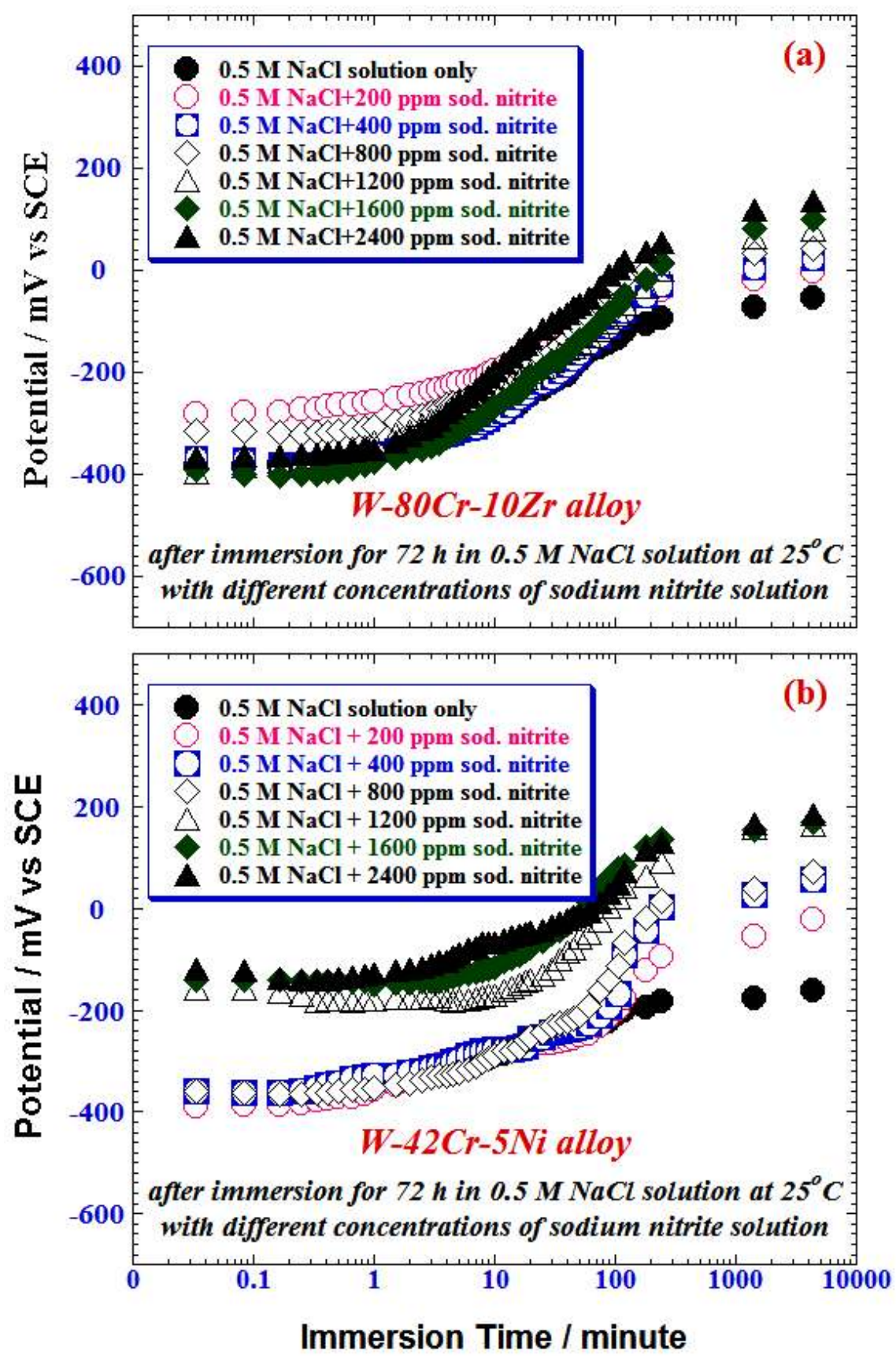

Fig. 3: Changes in open circuit potential of the sputter-deposited (a) $\mathrm{W}-80 \mathrm{Cr}-10 \mathrm{Zr}$ and (b) W$42 \mathrm{Cr}-5 \mathrm{Ni}$ alloys in $0.5 \mathrm{M} \mathrm{NaCl}$ solution open to air at $25^{\circ} \mathrm{C}$ in absence and presence of different concentrations of sodium nitrite, as a function of immersion time. 

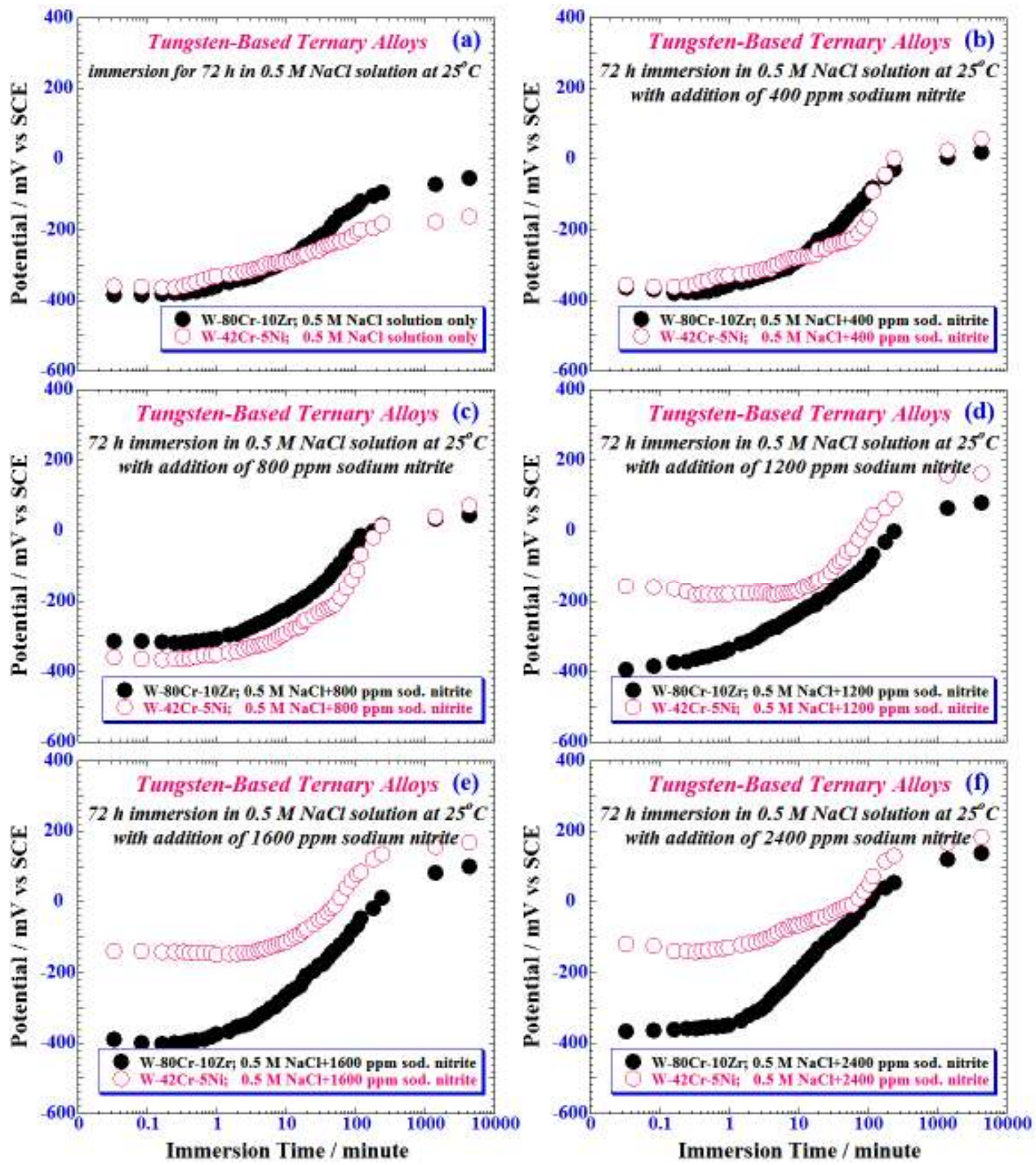

Fig. 4: Comparison of the change in open circuit potential of the sputtered $\mathrm{W}-80 \mathrm{Cr}-10 \mathrm{Zr}$ and $\mathrm{W}-42 \mathrm{Cr}-5 \mathrm{Ni}$ alloys in $0.5 \mathrm{M} \mathrm{NaCl}$ solution open to air at $25^{\circ} \mathrm{C}$ in absence and presence of different concentrations of sodium nitrite. 
Pokharel et al. / BIBECHANA 12 (2015) 1-12: p. 10

Figure 4 shows the comparative changes in OCP of the sputter-deposited $\mathrm{W}-80 \mathrm{Cr}-10 \mathrm{Zr}$ and $\mathrm{W}-42 \mathrm{Cr}$ $5 \mathrm{Ni}$ alloys in $0.5 \mathrm{M} \mathrm{NaCl}$ solution in absence and presence of $200 \mathrm{ppm}, 400 \mathrm{ppm}, 800 \mathrm{ppm}, 1200$ ppm, $1600 \mathrm{ppm}$ and $2400 \mathrm{ppm}$ concentrations of sodium nitrite. It is clearly observed that the open circuit potential of the $\mathrm{W}-42 \mathrm{Cr}-5 \mathrm{Ni}$ alloy is particularly shifted to more positive or noble than that of the $\mathrm{W}-80 \mathrm{Cr}-10 \mathrm{Zr}$ alloy. Consequently, it can be said that the more effective anodic inhibition effect is observed on the $\mathrm{W}-42 \mathrm{Cr}-5 \mathrm{Ni}$ alloy than $\mathrm{W}-80 \mathrm{Cr}-10 \mathrm{Zr}$ alloy. This behavior is also supported the results of showing higher corrosion rate by $\mathrm{W}-42 \mathrm{Cr}-5 \mathrm{Ni}$ alloy than by $\mathrm{W}-80 \mathrm{Cr}-10 \mathrm{Zr}$ alloy as shown above in Fig. 1.

\section{Conclusions}

The effect of sodium nitrite as an environmental friendly green corrosion inhibitor on the corrosion behavior of the sputter-deposited ternary $\mathrm{W}-80 \mathrm{Cr}-10 \mathrm{Zr}$ and $\mathrm{W}-42 \mathrm{Cr}-5 \mathrm{Ni}$ alloys in $0.5 \mathrm{M} \mathrm{NaCl}$ solution open to air at $25^{\circ} \mathrm{C}$ was studied using corrosion tests and open circuit potential measurements. From the results and discussion following conclusions are drawn.

Sodium nitrite use as a green corrosion inhibitor in $0.5 \mathrm{M} \mathrm{NaCl}$ solution was found to be effective to decrease the corrosion rate (nearly one order of magnitude) of the tungsten-based alloys with increasing the concentration of the inhibitor.

The corrosion inhibition efficiency was increased with increasing the concentration of sodium nitrite in $0.5 \mathrm{M} \mathrm{NaCl}$ solution and follows the Langmuir adsorption model of which indicates that sodium nitrite adsorbed onto the alloy surfaces in $0.5 \mathrm{M} \mathrm{NaCl}$ solution as a result the corrosion rate of the alloys is significantly decreased with addition of the inhibitor.

Experimentally obtained values of the standard free energy change $\left(\Delta \mathrm{G}_{\mathrm{ads}}^{\mathrm{o}}\right)$ of adsorption of sodium nitrite onto $\mathrm{W}-80 \mathrm{Cr}-10 \mathrm{Zr}$ and $\mathrm{W}-42 \mathrm{Cr}-5 \mathrm{Ni}$ alloys were found to be $-23.70 \mathrm{KJ} / \mathrm{mole}$ and -23.38 $\mathrm{KJ} /$ mole, respectively, suggested that the adsorption of inhibitor onto alloy surfaces is due to physical adsorption, not by the chemical adsorption.

The open circuit potential of the alloys was shifted to noble direction with increasing the concentration of the inhibitor that indicates that sodium nitrite acts anodic inhibitor in $0.5 \mathrm{M} \mathrm{NaCl}$ solution.

\section{References}

[1] H. H. Uhlig and R. W. Revie, in Corrosion and Corrosion Control; an Introduction to Corrosion Science and Engineering, $4^{\text {th }}$ Edition, John Wiley and Sons, New York, USA. (2008).

[2] J. Bhattarai, Frontiers of Corrosion Science. $1^{\text {st }}$ Edition, Kshitiz Publication, Kirtipur, Kathmandu, Nepal. (2010).

[3] J. O. M. Bockris, A. K. N Reddy and M. Gamboa-Aldeco, Modern Electrochemistry. $2^{\text {nd }}$ edition, Volumes 2A \& 2B, Plenum Publ. Co., New York, (2000).

[4] D. S. Kalyani and S. S. Rao, Chem. Sci. Rev. Lett., 2 (2014) 480. 
[5] X. Gaun, Impact of zinc orthophosphate inhibitor on distribution system water quality, $\mathrm{Ph} \mathrm{D}$ Thesis, Department of Civil and Environment Engineering, University of Central Florida, Orlando. (2007) pp. 1-180+XXI.

[6] V. Sribhurathy and S. Rejendran, Chem. Sci. Rev. Lett., 1(1) (2012) 25.

[7] M. Acharya, J. S. Chouhan, A. Dixit and D. K. Gupta, Chem. Mater. Res., 3(6) (2013) 16.

[8] V. S. Sundaram, S. Pitchai, K. Devarayan, G. M. Krishnan, A. Viccent and S. Nagarajan, Chem. Sci. Rev. Lett., 1(4) (2013) 195.

[9] E. S. Meresht, T. S. Farahani and J. Neshati, Corros. Sci., 54 (2012) 36. http://dx.doi.org/10.1016/j.corsci.2011.08.052

[10] V. Afshari and C. Dehghanian, J. Solid State Electrochem., 14 (2010) 1855. http://dx.doi.org/10.1007/s10008-010-1066-0

[11] Q. B. Zhang and Y. X. Hua, Electrochim. Acta 54 (2009) 1881. http://dx.doi.org/10.1016/j.electacta.2008.10.025

[12] V. Chandrasekarn, M. Muralisankar and A. Vasila, J. Net. Mater. Soc., 48(2) (2006) 93.

[13] J. G. Sriram, M. H. Sadhir, Chem. Sci. Rev. Lett., 2(5) (2014) 402.

[14] V. G. Vasudha and K. S. Priya, Chem. Sci. Rev. Lett., 2(6) (2014) 435.

[15] Gy. Vastag, E. Szöcs, A. Shaban and E. Kálmán, Pure Appl. Chem., 73(12) (2001) 1861.

[16] J. Lei, L. Li and F. Pan, Environmental friendly corrosion inhibitors for magnesium alloys. in Frank Czerwinski (ed) Magnesium Alloys-Corrosion and Surface Treatments, Chapter-4. InTech Europe University Campus STeP Ri Slavka Krautzeka 83/A 51000 Rijeka, Croatia. (2011) 47-64 pp.

[17] D. Prabhu and P. Rao, Intl. J. Corros., Article ID 945143 (2013) 1.

[18] G. O. Ilevbare and G. T. Burstein, Corros. Sci., 45 (2003) 1545. http://dx.doi.org/10.1016/S0010-938X(02)00229-9

[19] M. W. Kendig and R. G. Buchheit, Corros., 59(5) (2003) 379. http://dx.doi.org/10.5006/1.3277570

[20] D. VK and J. Bhattarai, Nepal J. Sci. Technol., submitted (2015).

[21] D. B. Subedi, D. B. Pokharel and J. Bhattarai, Intl. J. Appl. Sci. Biotechnol., 2(4) (2014).

[22] D. B. Subedi, D. B. Pokharel and J. Bhattarai, Chem. Sci. Rev. Lett., 3(12) (2014).

[23] F. Eghbali, M. H. Moayed, A. Davoodi and N. Ebrahimi, Corros. Sci., 53 (2011) 513. http://dx.doi.org/10.1016/j.corsci.2010.08.008

[24] R. A. Celeste and V. A. Vieira, Electrochim. Acta 49 (2004) 2779. http://dx.doi.org/10.1016/j.electacta.2004.01.039

[25] V. S. Saji and J. Thomas, Corros. Sci. 92 (2007) 51.

[26] M. R. Ali, C. M. Mustafa and M. Habib, J. Sci. Res. 1(1) (2009) 82.

[27] S. A. M. Refaey, S. S. Abd El-Rehim, F. Taha, M. B. Saleh and R. A. Ahmed, Appl. Surf. Sci., 158 (2000) 190. http://dx.doi.org/10.1016/S0169-4332(00)00016-7

[28] M. J. Pryor and M. Cohen, J. Electrochem. Soc., 100 (1953) 3. http://dx.doi.org/10.1149/1.2781106

[29] J. P. G. Farr and M. Saremi, Surf. Technol., 17 (1982) 199. 
[30] C. M. Mustafa and S. M. S. I. Dulal, British Corros. J., 32 (1997) 133. http://dx.doi.org/10.1179/bcj.1997.32.2.133

[31] P. L. Kharel, S. P. Sah and J. Bhattarai, Nepal J. Sci. Technol., 14(2) (2013) 73. http://dx.doi.org/10.3126/njst.v14i2.10418

[32] J. Bhattarai, Afr. J. Pure Appl. Chem., 5(8) (2011) 212.

[33] J. Bhattarai, Scientific World, 9(9) (2011) 34. http://dx.doi.org/10.3126/sw.v9i9.5515

[34] J. Bhattarai and B. R. Aryal, Scientific World, 9(9) (2011) 39. http://dx.doi.org/10.3126/sw.v9i9.5516

[35] B. R. Aryal and J. Bhattarai, J. Nepal Chem. Soc., 25 (2010) 75. http://dx.doi.org/10.3126/jncs.v25i0.3305

[36] J. Bhattarai, J. Nepal Chem. Soc., 26 (2010) 13. http://dx.doi.org/10.3126/jncs.v26i0.3625

[37] R. R. Kumal and J. Bhattarai, J. Nepal Chem. Soc., 25 (2010) 93. http://dx.doi.org/10.3126/jncs.v25i0.3312

[38] J. Bhattarai, Trans. Mater. Res. Soc. Jp., 35(1) (2010) 1.

[39] P. K. Kharel and J. Bhattarai, J. Nepal Chem. Soc., 24 (2009) 3. http://dx.doi.org/10.3126/jncs.v24i0.2380

[40] J. Bhattarai and P. L. Kharel, J. Inst. Sci. Technol., 16 (2009-10) 141.

[41] J. Bhattarai, Scientific World, 7(7) (2009) 24. http://dx.doi.org/10.3126/sw.v7i7.3819

[42] B. D. Cullity, Elements of X-ray diffraction, $2^{\text {nd }}$ edition, Addison-Wesley Publ. Co. Inc., Massachusetts. (1977) 101-102 pp.

[43] M. A. Hegazy, A. S. El-Tabei, A. H. Bedair and M. A. Sadeq, Corros. Sci., 54 (2012) 219. http://dx.doi.org/10.1016/j.corsci.2011.09.019

[44] N. A. Negm, M. A. Yousef and S. M. Tawfik, Rec. Patents Corros. Sci., 3(1) (2013) 1. http://dx.doi.org/10.2174/22106839112029990003

[45] I. Ahamad, R. Prasad and M. A. Quraishi, Mater. Chem. Phys., 124 (2010) 1155. http://dx.doi.org/10.1016/j.matchemphys.2010.08.051

[46] M. Dahmani, A. Et-Touhami, S. S. Al-Deyab, B. Hammouti and A. Bouyanzer, Intl. J. Electrochem. Sci., 5 (2010) 1060.

[47] K. F. Khaled, Corros. Sci., 52 (2010) 2905. http://dx.doi.org/10.1016/j.corsci.2010.05.001 